\title{
VIDAS HOMOAFETIVAS EMTEMPOS DE REPRESSÃO: MEMÓRIA, IDENTIDADE E HISTÓRIA EM DOIS ROMANCES AMAZÔNICOS
}

\section{HOMOAFFECTIVE LIVES IN TIME OF REPRESSION: MEMORY, IDENTITY AND HISTORY IN TWO AMAZONIAN NOVELS}

\section{Rubenil da Silva OLIVEIRA* UFPA \\ Carlos Henrique Lopes de ALMEIDA** UFPA \\ Maria do Perpétuo Socorro Galvão SIMÕES ${ }^{* * *}$ UFPA}

Resumo: O presente artigo pretendeu analisar as vidas homoafetivas em tempos de repressão nos romances História de Mayta (1984), de Mário Vargas Llosa e Olho de Boto (2015), de Salomão Larêdo. Para isto foi necessária leitura de Green (2000), Figari (2007), Okita (2015), Trevisan (2002), Mott (1994) e outros autores. Nos textos lidos depreendeu-se que o tratamento dado aos homoafetivos nos locais e tempos de guerra exige o sufocamento da sexualidade destes a partir da sua invisibilização, embora eles sejam partidários da esquerda como é o caso de Mayta, pois para os líderes políticos a orientação homoafetiva não é digna de confiança. A desconfiança que recai sobre a identidade homoafetiva tem origem no fato de que essa identidade sexual é tomada como um entre-lugar entre o masculino e o feminino. Portanto, viver a homoafetividade em tempos de repressão era silenciar o desejo sexual que habitava dentro de si em favor da ordem social, caso contrário era julgado como um subversivo, aquele que se colocava contra os discursos dos governantes autoritários e, por essa razão, deveriam ser punidos com os rigores da lei.

Palavras-chave: Homoafetividades. Identidade. Repressão. Silêncio. História.

Abstract: This article aims to analyze homoaffective lives in times of repression in the novels História de Mayta (1984), by Mario Vargas Llosa and Olho de Boto (2015) by Salomão Larêdo. For this, it was necessary to read Green (2000), Figari (2007), Okita (2015), Trevisan (2002), Mott (1994) and other authors. In the texts read it is understood that the treatment given to the homosexual in the places and times of war demands the suffocation of the sexuality of these from their invisibilization, although they are left-wing supporters like is the case of Mayta, therefore for the political leaders the orientation homoeffective is not trustworthy. The suspicion that falls on the homosexual identity stems from the fact that this sexual identity is

\author{
* Doutorando em \\ Letras - Estudos \\ Linguísticos e \\ Estudos Literários, \\ área de concentração \\ Estudos Literários, da \\ Universidade Federal \\ do Pará. Bolsista \\ Fapespa. \\ ** Doutor em Letras \\ e Linguística pela \\ Universidade Federal \\ de Goiás, atualmente \\ é Professor Adjunto \\ I da Universidade \\ Federal do Pará. É \\ Professor permanente \\ do Programa de \\ Pós-Graduação em \\ Estudos Linguísticos \\ e Estudos Literários. \\ *** Doutora em \\ Letras Vernáculas \\ pela Universidade \\ Federal do Rio de \\ Janeiro, atualmente \\ é Professora Adjunta \\ IV da Universidade \\ Federal do Pará. \\ É Professora \\ permanente do \\ PPGL-UFPA.
}


taken as an inter-place between the masculine and the feminine. Therefore, live the homoaffectivity in times of repression was to silence the sexual desire that habited inside itself in favor of the social order, otherwise it was judged like a subversive, that one that was placed against the discourses of the authoritarian rulers and, for that reason, they should be punished with the rigors of the law.

Keywords: Homoaffectivities. Identity. Repression. Silence. History.

\section{Introdução}

Identificar-se homoafetivo, nas sociedades primitivas, não era imoral nem pecado, era parte do sagrado e da administração da cidade, pessoas que carregavam poderes mágicos, capazes de abençoar ou amaldiçoar uma união ou nascimento como as hijras na cultura indiana. As noções de pecado e imoralidade associadas à prática do amor e desejo eróticos entre pessoas do mesmo sexo só passaram a ser vistas a partir da difusão do pensamento cristão medieval e os seus praticantes chamados de sodomitas, condenados à morte na fogueira ou por enforcamento e enterrados em cova rasa sem nenhuma identificação. Esse ideário manifestado pelo Cristianismo prevalece na invasão dos europeus ao chamado Novo Mundo conforme consta nas crônicas e relatos dos viajantes e missionários e toma como pressuposto a observação da vida das populações nativas.

Por sua vez, no mundo helênico, a iniciação sexual dos jovens pelos preceptores era permitida, porém se dava só até os pupilos atingirem a idade adulta, depois de passado o período de aprendizagem, os últimos tornar-se-iam agora preceptores e conceberiam núpcias com o sexo oposto. Na Idade Média, o predomínio do Cristianismo traz o discurso de pecado e ódio à identidade sexual homoafetiva e para isso se valia dos textos bíblicos, por exemplo, a cidade de Sodoma e Gomorra foi destruída por causa da presença massiva dos homoafetivos e da prostituição. Já na Idade Moderna e na contemporaneidade, embora se propague os discursos humanistas, o olhar acerca das homoafetividades continua mergulhado no discurso religioso contrário a ela e/ou no silenciamento dos que assumem essa orientação sexual.

A história das homoafetividades dá conta de que a repressão sempre foi mais forte que a aceitação e tolerância aos homoafetivos nas sociedades, pois até mesmo os Códigos Penais previam punições a qualquer indício dessa orientação sexual que fosse demonstrada em público. O Código Penal de 1830 não mais traz a identificação do sujeito homoafetivo como sodomita, mas não elimina a culpabilidade deste sujeito, o abraço entre dois homens em público era motivo para a condenação e mais ainda o fato de o homem ultrapassar a idade de trinta anos, não conceber núpcia e ter sempre outro homem por perto. É imperativo afirmar que a política repressora do higienismo do fim do século XIX se assemelha à existente durante os regimes ditatoriais na América Latina, onde os sujeitos homoafetivos recebiam 
tratamentos à base de choques elétricos e internação nos sanatórios como meio de se curar da inversão (COWAN, 2014).

O objetivo deste artigo é analisar as vidas homoafetivas em tempos de repressão nos romances História de Mayta (1984), de Mário Vargas Llosa e Olho de Boto (2015), de Salomão Larêdo, bem como; identificar a memória e história das homoafetividades no espaço amazônico nos períodos de repressão e; verificar as aproximações e dissonâncias do discurso literário nos romances supramencionados. Para isso, busca suporte em diversos autores acerca da literatura, memória, história, da antropologia, sobretudo, acerca das homoafetividades no espaço latino-americano, onde estão situadas as amazônias peruana e brasileira.

Em conformidade com os objetivos e a metodologia deste artigo, ele foi organizado em partes. A primeira comporta conceitos que serão explorados nas demais, bem como os objetivos, a metodologia e a organização do trabalho. A segunda é o desenvolvimento, o qual foi dividido em três partes menores: História e memória das homoafetividades em períodos de repressão; Memória, identidade e homoafetividade em Historia de Mayta; Olhares sobre memória e violência na história das homoafetividades no imaginário amazônico brasileiro. Por último, a conclusão trata das compreensões a que se chegou após os entrecruzamentos da teoria e das leituras literárias em relação aos objetivos propostos para a escrita.

\section{História e memória das homoafetividades em períodos de repressão}

Para realizar esta análise faz-se necessário o entendimento das categorias história, memória, repressão e literatura. Por se tratar de um estudo de um assunto que é histórico para o campo do literário, entendido como ficção, aumento da realidade e das lacunas da memória vivida, mas que é interdisciplinar por convergir temas estudados pela História, Antropologia e Sociologia. Os dois romances amazônicos - História de Mayta (Peru) e Olho de Boto (Brasil) carregam a força do imaginário de suas populações sobre os homoafetivos. O primeiro aborda o movimento guerrilheiro do Peru, nos anos de 1950, antes que acontecesse a Revolução Cubana e o último se inicia com a discussão acerca da realização do primeiro casamento homoafetivo, na pequena Cametá, Belém, Brasil, em dezembro de 1967, noticiado no jornal Folha Vespertina ${ }^{1}$, àquela época.

Encara-se o casamento homoafetivo apontado por Salomão Larêdo como um fato ficcional, até mesmo o jornal é uma invenção, uma recriação não do tempo da repressão, mas do cotidiano, uma vez que só em maio de 2011, o Supremo Tribunal Federal do Brasil veio a reconhecer a legalidade da união homoafetiva. Neste caso, nota-se que a criação literária subverte a ordem do real, escrever um romance não precisa da fidedignidade à história
${ }^{1}$ Acredita-se que o jornal é uma invenção do autor, pois em pesquisa feita na Hemeroteca da Biblioteca Nacional Digital, mostra que os fatos noticiados acerca de casamentos entre homossexuais em jornais, na década de 1960 a 1969, estão relacionados às representações cinematográficas e no teatro. No Jornal do Brasil, de 11 de julho de 1967, Yan Michalski critica a peça Dois barbeiros numa noite suja, de Charles Dyers, a qual tem uma cena de casamento homoafetivo. No mesmo jornal, em 06 de outubro, de 1967, o jornalista Yan Michalski critica a peça $O$ assassinato da irmã Geórgia, de Frank Marcus, traduzida por Millôr Fernandes e encenada no Teatro Gláucio Gil, à época, que trata de um casamento entre lésbicas. No Tribuna da Imprensa, em 06 de junho de 1967, Fausto Wolff tece uma crítica à representação da peça de Charles Dyers feita pelos atores Jardel Filho e Sérgio Viotti, na qual estabelece uma comparação com a peça de Frank Marcus. No Correio da Manhã, de 12 de dezembro de 1968, há severa crítica à montagem do filme The boys in the band, que uma peça da Broadway, dirigida por Robert Moore e tem também a representação do casamento homoafetivo. No Jornal dos Sports, edição de 30 de junho de 1967, a jornalista Isabel Edmara, fala da estreia da montagem da peça de Charles Dyers, feita no Teatro Princesa Isabel, no Rio de Janeiro, encenada por Jardel Filho e Sérgio Viotti. 
dos fatos reais como marca do passado, assim, assume-se que a "dialética da história parece resumir-se numa oposição - ou num diálogo - passado/ presente (e/ou presente/passado)” (LE GOFF, 2013, p. 9). Desse modo, esse artigo, por se tratar de um estudo literário assume o sentido de história como narrativa, pois "uma história é uma narrativa, verdadeira ou falsa, com base na 'realidade histórica’ ou puramente imaginária - pode ser uma narrativa histórica ou uma fábula” (LE GOFF, 2013, p. 22).

Vê-se que na visão de história adotada por Salomão Larêdo e ainda por Mário Vargas Llosa, embora tenha algum contato com a realidade vivenciada pelos homoafetivos à época, a criação literária “nunca é uma história fiel, há sempre nele mais mentiras do que verdades” (JOZEF, 1984, p. 1). Por essa razão, o conceito de história mais apropriado a este artigo é o de narrativa, visto que a história enquanto narrativa pode ser falseada, não obrigatoriamente real, mas uma criação no qual se inserem dados e afirmações que extrapolam os limites do acontecimento real. Neste sentido, os romances não são documentos da realidade, são fatos a que se acrescentam ideias para construir a literatura como a derivação “de convenções e intenções mais ou menos conscientes que se estabelecem do lado de quem escreve e são reconhecidas como tais do lado de quem lê" (DERRIDA, 2014, p. 14).

A verdade é que os homoafetivos àquela época e, sobretudo, nos contextos de repressão não eram tidos como dignos de confiança, mesmo que se mostrassem favoráveis às decisões do governo, visto que: “os teóricos anticomunistas e as forças de segurança começaram a demonizar a identidade gay” (COWAN, 2014, p. 29). Porém, o discurso de segregação dos homoafetivos não diz respeito apenas aos anticomunistas, pois mesmo nos locais onde os comunistas ascenderam ao poder, por exemplo, Cuba, deu-se continuidade à tese de que a homoafetividade representava a decadência da sociedade burguesa. Neste panorama, o governo castrista ao assumir o poder em Cuba manda "os homossexuais ao campo para trabalharem nas unidades militares para o aumento de produção. Forçando-os a isso, o governo acreditava que era a forma de eliminar o comportamento antirrevolucionário deles” (OKITA, 2015, p. 59). Desse modo, vê-se que mesmo Mayta lutando, sendo desde cedo um revolucionário, não era benquisto pelos demais que estavam ao seu lado na revolução peruana.

Por sua vez, vê-se que, no Brasil, os anos de 1964 a 1985 são marcados pelo domínio do regime militar e a história dos homoafetivos dividida entre o domínio e a represália à liberdade de assumir essa identidade sexual e de outro, o crescimento efetivo dos movimentos de libertação dos gays e das publicações, como os jornais. Sobre o primeiro olhar, os homoafetivos eram vistos como inimigos do governo e, por isso, uma ameaça à segurança nacional um "complô arquitetado pelos inimigos do estado" (COWAN, 2014, p. 29). Todavia, percebe-se, afinal que, embora houvesse manifestações contrárias à orientação homoafetiva, pode-se dizer também 
que "a ditadura inteira, nem agências e facções dentro dela, perseguiram a homossexualidade com alacridade extraordinária; sem dúvida, a atividade homossexual não foi a razão principal por que tantos brasileiros sofreram vigilância, detenção, tortura e morte” (COWAN, 2014, p. 49). O olhar era outro, os homoafetivos eram símbolos da degeneração da moral, da família e dos bons costumes sociais, visão essa que é assumida nas obras de Vargas Llosa e Larêdo.

Por sua vez, as escritas de Mário Vargas Llosa e de Salomão Larêdo parecem comprometidas com a memória que guardam do seu lugar de nascimento e experiência, mesmo que os lugares - Peru (Barranco, Miraflores, San Isidro, Jauja) e Brasil (Cametá, Pará) sejam distintos. Na contramão a essa aparente semelhança, diz-se que “os loci da memória não devem ser muito parecidos. [...] muitos espaços divididos por colunas não são bons, pois a semelhança entre eles pode gerar confusão” (YATES, 2016, p. 24).

No tocante aos espaços das narrativas em análise percebeu-se que os locais de Vargas Llosa e Larêdo são marcados por olhares e situações totalmente distintas, respeitando assim o que diz Yates acerca dos lugares da memória. Essa diferenciação se estabelece em relação ao tempo e espaços, sobretudo, acerca do último, pois a selva amazônica paraense, uma vez que a narrativa de Larêdo transcorre a maior parte na zona rural de Cametá, enquanto a de Vargas Llosa começa pelos distritos peruanos onde a personagem-título - Mayta - depara-se com a pobreza e desigualdade social que o motivam a se tornar um revolucionário.

\subsection{Homoafetividade e repressão das subjetividades em História de Mayta, de Mário Vargas Llosa}

O romance Historia de Mayta foi publicado em 1984. O tema central é a política nos anos que antecederam a Revolução Cubana, nesta condição o enredo embora seja construído a partir do real impacta o leitor pelo modo como o narrador apresenta as transformações da protagonista Mayta. As transformações da personagem são também reflexos da maturidade do eu, do nascimento de um desejo coletivo de igualdade social a partir dos movimentos revolucionários eclodidos na América Latina, na segunda metade do século XX. A narrativa aborda o processo formativo da consciência político-ideológica de um velho trotskista, o qual quando jovem era possuidor de uma fé extremista, sendo capaz até mesmo de jejuar em favor dos mais pobres e é essa fé sectária que o orienta a ser um revolucionário peruano. Sobre o processo de criação da obra, o autor revela:

A diferencia de otros escritores que pueden partir para escribir de una ficción, de una imagen, de una fantasía, de un sueño, yo siempre he partido de alguna experiencia concreta vivida directamente por mí, o indirectamente por algo que oí o he leído. Este punto de partida de 
una realidad concreta, de una experiencia vivida, inmediata, ha sido la condición realmente indispensable para que un asunto, un personaje, me resulten estimulantes y me urjan a escribir.

En el caso de Historia de Mayta, el punto de arranque es una noticia de pocas líneas que leí un día de 1962 en un periódico de París, donde yo vivía entonces. En Le Monde encontré una nota perdida en las páginas de noticias extranjeras que se refería a mi país. Se hablaba de que había habido un intento insurreccional en una ciudad del centro, la ciudad de Jauja, que había sido develado a las pocas horas. Había algunos muertos y algunos heridos. Eso era todo (MERGIER, 1985, p. 10).

Observa-se no fragmento que para narrar o vivido é preciso que o sujeito recorra às lembranças depositadas na memória e, estas, por sua vez, são parte da história vivida por alguém, assim a notícia extraída do jornal francês Le Monde sobre a revolução peruana é real. Contudo, a narração não prima pela suposta verdade, o autor tem consciência de que precisa produzir novos significados para os fatos e de "coerência interna no que tange ao mundo imaginário das personagens e situações miméticas; ou mesmo a visão profunda - de ordem filosófica, psicológica ou sociológica - da realidade” (CANDIDO et al, 2014, p. 18). Ainda na busca da manutenção da lógica interna no texto, Vargas Llosa emprega em Historia de Mayta o conceito de lembrança como "a recuperação do conhecimento ou da sensação ocorrida. É um esforço deliberado para encontrar seu caminho entre os conteúdos da memória, perseguindo aquilo de que se quer lembrar” (YATES, 2016, p. 54).

A coerência pretendida por Candido et al (2014) também se apresenta em Yates (2016) à medida que esta reconhece a necessidade de o escritor buscar na memória a lembrança dos fatos ocorridos, no caso, a notícia acerca dos mortos e feridos de Jauja. Isso contribui para os processos de criação e evolução da narração, além de demonstrar que a história da humanidade “é entrelaçada por motivações, propósitos, ações, medos, esperanças, linguagens, leis e costumes, fábulas, ritos, mitos, instituições” (ROSSI, 2010, p. 137). Na obra de Vargas Llosa essa motivação para a participação na política e o desejo de estar ao lado dos mais pobres é manifestada desde a meninice de Mayta, particularmente, na saída do Colégio Salesiano quando ainda era estudante e durante as aulas de catecismo.

Admite-se que a literatura "é coletiva, na medida em que requer uma certa comunhão de meios expressivos (a palavra, a imagem) e mobiliza afinidades profundas que congregam os homens de um lugar e de um momento - para chegar a uma 'comunicação'” (CANDIDO, 2000, p. 127). Nesta perspectiva, vê-se que Historia de Mayta, além de combinar esses elementos que constituem a obra literária, também comunica acerca do momento político vivenciado no Peru, nos anos de 1950, e ainda incorpora a visão dada pela sociedade aos homoafetivos naquela época. Entretanto, interessa aqui tratar da homoafetividade de Mayta e os silêncios acerca desta 
identidade, uma vez que a narração demonstra haver maior preocupação com a identidade revolucionária de Mayta e não sua orientação sexual.

É esse silêncio que permite ao narrador somente na metade do capítulo quatro mencionar a orientação sexual da personagem, pois antes disso somente o leitor mais atento perceberá que são deixados indícios da sexualidade dele. Desse modo, compreende-se que memória e identidade estão imbricadas e assim a memória poderia ser definida como a "afecção produzida graças à sensação ‘na alma e na parte que a conduz”” (RICOUER, 2010, p. 36). Nesta perspectiva, constata-se que o sujeito é afetado pelo outro e essa afetação constitui parte das experiências pelas quais passam todos os sujeitos reais ou imaginários, por exemplo, Anatólio, mesmo resistindo ao primeiro toque de Mayta em seu corpo: "Deixe eu pegá-la - murmurou, voz agonizante, sentindo que seu corpo ardia. - Deixe, Anatólio” (VARGAS LLOSA, 1984, p. 100). Mais adiante, acaba por aceitá-lo: "Você pode pegá-la, se quiser ouviu-o sussurrar, timidamente. E, mais baixo ainda, assustado: Mas nada mais que isso, Mayta” (VARGAS LLOSA, 1984, p. 110).

Mesmo que permita a Mayta tocá-lo em suas partes íntimas, sabe-se que Anatólio era heterossexual, revolucionário e mais jovem que aquele, mas lhe adverte de que era somente pegar e não teria entre eles nenhum contato mais íntimo, ou seja, não teria a realização do sexo. Esta advertência sugere que Anatólio por não ter experiências homoafetivas anteriores tem medo de um contato sexual com o sexo igual; outra leitura possível é de que mesmo tentando resistir, ele se vê afetado pela presença e desejo erótico de Mayta, porém não quer que existam rastros desse contato. Para ele é preferível que seja negada a possibilidade de existência do contato sexual entre pessoas do mesmo sexo, pois não quer carregar a "imagem-lembrança” (RICOUER, 2010, p. 428) do seu consentimento, por isso, também o esclarecimento de que nada mais existiria entre eles.

Ao situar a análise sobre a homoafetividade de Mayta percebe-se que as "personagens são construídas em torno de um modelo, direta ou indiretamente conhecido, mas que apenas é um pretexto básico, um estimulante trabalho de caracterização, que explora ao máximo as suas virtualidades por meio da fantasia” (CANDIDO et al, 2014, p. 72). A assertiva evidencia que o ato de criação das personagens na literatura pressupõe a representação de identidades, as quais podem ter semelhanças com pessoas reais, vestígios da memória ou ser apenas parte do imaginário dos seus autores. Por essa razão, acrescenta-se que a "memória é constituinte da identidade pessoal que permite ao sujeito pensar-se idêntico no tempo, graças, particularmente à função narrativa” (CANDAU, 2005, p. 143). Em conformidade com o pensamento do teórico percebe-se que o ato criacionista na literatura é parte das experiências do sujeito escrevente, às quais ele pode atribuir novos significados, conforme expresso no excerto a seguir. 
Talvez aí esteja a explicação - pensa, brincando com piteira. - É possível ter confiança em um homossexual? Um ser incompleto, feminino, está vulnerável a todas as fraquezas, incluída a traição.

Animando-se, dominado pelo tema, afasta-se de Mayta e dos acontecimentos de Jauja e me explica que o homossexualismo está intimamente ligado à divisão de classes e à cultura burguesa. Porque não existem quase homossexuais nos países socialistas? Não é por acaso, não se deve a que o ar que se respira nessas altitudes faça o homem mais virtuoso. Lástima que os países socialistas estejam ajudando à subversão no Peru. Porque há nessas sociedades muito o que imitar. Nelas já desapareceu a cultura do ócio, o vazio anímico, essa insegurança existencial típica da burguesia que duvida, inclusive, do sexo com o qual nasceu. O maricão é uma indefinição, rimou e é verdade (VARGAS LLOSA, 1984, p.101).

Sobre a contrariedade à presença da homoafetividade nos países socialistas, este fato teve origem com os stalinistas, em 1929, para os quais essa orientação sexual era produto da decadência burguesa, uma perversão fascista ou ainda um desvio da pureza moral (OKITA, 2015). No entanto, as homoafetividades do masculino e do feminino não eram apresentadas da mesma forma, somente a masculina era vista "como uma prática degenerativa, furtiva e de efeminados, que elas vaga e variavelmente associaram com subversão e vulnerabilidade política” (COWAN, 2014, p. 32). Isso ocorre porque as mulheres apresentam menor carga de estereótipos que os homens que se identificam como homoafetivos e, esta orientação sexual era tida como uma deliberada ameaça à moralidade social, um pecado contra a família e ao processo reprodutivo da Nação.

Embora se perceba um novo olhar sobre as homoafetividades, muitos deles ainda carregam o peso do julgamento contrário tal qual ocorria no período da Inquisição e a força que a palavra dos delatores tinha contra aquele que era delatado. Neste sentido, ao tratar das homoafetividades na América Latina da contemporaneidade pode-se sustentar que muitos homoafetivos foram acusados de “atentado ao pudor ou prática da prostituição, incontável número de pederastas foram chantageados, encarcerados e torturados pelos agentes da nova ordem policial” (MOTT, 1994, p. 10). A tortura e o cárcere eram medidas de repressão usadas pelas forças policiais tidas como autoridade nos sistemas políticos ditatoriais e para "toda essa violência, a polícia conta com o respaldo da própria sociedade, já que ninguém está ligando se uma bicha ou sapatão estão sendo presos na rua [...]” (OKITA, 2015, p. 73).

Essa acusação de atentado adquire no romance outra configuração, ele não é mais ao pudor ou prostituição, não se julga a homoafetividade do protagonista, mas a sua participação em atos subversivos e de desordem política. Mayta é condenado a quinze anos de prisão acusado do sequestro e posterior suicídio da filha do Senhor Fuentes, administrador da Agência do Banco de Crédito em Pueblo Livre. A tática usada pelos militares era a mesma usada pelos julgadores da Inquisição - a tortura. Era essa a ordem 
policial, torturavam o sujeito até que ele se confessasse culpado, pois nem o dinheiro, nem os ajudantes do sequestro apareceram, conforme expresso em:

Não demorou muito e a polícia anunciava a detenção do cabeça do grupo - Mayta - e que seus cúmplices seriam também logo presos. Segundo a polícia, Mayta reconheceu sua culpabilidade e revelou todos os pormenores. Nem os cúmplices nem o dinheiro apareceram nunca. No julgamento, Mayta negou que houvesse participado no sequestro, ou sequer sabido dele, e insistiu em que a falsa confissão que lhe tinha sido arrancada com torturas. O processo durou vários meses, no princípio entre certo alvoroço dos jornais, que logo diminuiu. A sentença foi de quinze anos de prisão e o tribunal reconheceu-o culpado de sequestro, extorsão criminosa e homicídio indireto, apesar de seus protestos de inocência. Afirmava ele que, no dia do sequestro, estava em Pacasmayo, vendo um possível trabalho, mas isso não pode ser provado. E foram muito prejudiciais a ele os depoimentos dos Fuentes. Ambos garantiram que a sua voz e seu físico correspondiam a um dos indivíduos mascarados (VARGAS LLOSA, 1984, p. 295).

O fragmento demonstra que a repressão praticada pelas forças policiais aproximava-se da violência praticada pelos europeus e religiosos contra os indígenas durante as invasões do Novo Mundo para que estes assimilassem a língua e a cultura daqueles. A violência praticada teria como resposta o silêncio o qual era "desejado pelo imperialismo cultural, ou ainda o eco sonoro que apenas serve para apertar ainda mais os laços do conquistador. Falar, escrever, significa: falar contra, escrever contra” (SANTIAGO, 2000, p. 17). O ato de resistir a esse impacto da violência é ir contra a cultura de dominação que sempre massacrou os grupos sociais como as mulheres, crianças, negros e também os homoafetivos. No caso, ao trazer uma personagem que é homoafetiva em tempos de forte repressão, o autor vislumbra um novo horizonte de expectativas para a homoafetividade.

Historia de Mayta procura romper com a cultura do silencio das homoafetividades nos tempos da revolução peruana. É ficção, mas a tortura, a delação sem que houvesse uma acareação com o delator e a repressão da força armada encontra reminiscências com a Inquisição e com as invasões europeias no Novo Mundo. Ressalta-se que recorrer à memória é um caminho possível para que se possa reconstituir a história dos povos e grupos sociais, no caso do romance de Mário Vargas Llosa - a trajetória dos homoafetivos e sua inserção social. Portanto, prevalece no romance a busca de um novo olhar para o homoafetivo, pois em tempos de repressão os que assumem esta orientação sexual não são presos e torturados apenas por isso, mas por irem contra a moralidade pregada pela estrutura social e a moral das sociedades burguesas. 


\subsection{Olhares sobre memória e violência na história das homoafetividades no imaginário amazônico brasileiro}

Olho de Boto, do escritor cametaense Salomão Larêdo, publicado em 2015, é um romance transgressivo para a literatura do norte do Brasil, não apenas por se enquadrar como literatura homoafetiva, campo da literatura ainda pouco explorado pelos escritores dessa região, incluindo os contemporâneos. O autor transgride por diversos motivos: 1. tematiza um casamento homoafetivo durante a Ditadura Militar em plena selva amazônica brasileira; 2. a narração enquadra-se como novo romance e parte da notícia de um casamento gay publicada em um jornal fictício - Folha Vespertina, já existiram outros romances iniciados com notícias de jornal na literatura brasileira $^{2}$, mas não se tratava de jornal ficcional; Outra inovação na narrativa é a divisão não em capítulos, sim em estações ${ }^{3}$ e; 3 . reúne narrativas orais e vocabulário que remontam o imaginário das comunidades amazônicas que se mesclam a histórias reais, além de propor uma fusão entre o sagrado e o profano.

No tocante aos olhares sobre a homoafetividade nas comunidades amazônicas, tomam-se os aspectos da memória e violência, pois ao mencionar os membros da comunidade que assistem ao julgamento de Inajacy e Inajá, o narrador faz uma cartografia dos grupos sociais excluídos na história: "A comunidade - índios, caboclos, roceiros, ribeirinhos, negros, remeiros, lavradores, reunida no meio do campo de futebol observa, quieta, muda, medrosa, sem voz, sem vez, pasma!” (LARÊDO, 2015, p. 15). Evidencia-se a exclusão desses grupos à medida que o narrador afirma que a eles não cabe o domínio da voz e da vez, inclusive são mudos, quietos, medrosos e, por esta razão, comportam-se apenas como espectadores, como se conscientes de que estão dominados e esquecidos no meio da selva amazônica. Desse modo, a violência que impera sobre a comunidade se dá em igual força no julgamento e domínio dos homoafetivos, a observar no modo como a eles se refere Ponciano, o Juiz da Saúde.

\section{Ponciano perguntou: Quem és tu?}

Uma mulher!

Ponciano perguntou: Que farei com isto que se diz mulher?

E a turba, orientada, conduzida, contratada pelos representantes dos mandachuvas, dos pica-grossas, das classes conservadoras, das autoridades, dos graúdos, dos que têm o poder e que compunham o conselho de sentença, dizia: Que leve uma grande pisa! Que seja castigado! Dá um banho de urtiga braba pra nunca mais ele vir com graça (LARÊDO, 2015, p. 15, ênfase do original).

O excerto revela que a violência imposta contra a identidade homoafetiva não parte somente do Estado e seu braço armado - a polícia - mas também do imaginário social, é o povo quem julga imoral a liberdade sexual
${ }^{2}$ Capitães da Areia, de Jorge Amado, publicado em 1937, parte de notícias de jornal sobre os meninos que praticavam pequenos furtos na Bahia e que por diversas vezes foram recolhidos ao Reformatório.

${ }^{3}$ Nome extraído da Bíblia e que se refere às passagens utilizadas pelas Igrejas cristãs para contar os últimos momentos da vida de Jesus Cristo, do julgamento à ressurreição. Percebeu-se assim que há uma intertextualidade nessa estrutura, pois há a retomada de outro texto já conhecido pelo público. 
do outro, isso a partir da medida sobre as coisas e os homens ensinada pela moral cristã. Porque a "Igreja era o aparelho preferencial de definição, produção de sentidos e controle dos discursos sobre sexualidade. Na Idade Média, é a Igreja quem não só disputa o controle das consciências (e leva à fogueira os dissidentes), mas quem também assume o controle da sexualidade” (FIGARI, 2007, p. 60). Neste caso, vê-se que o julgamento das pessoas resulta do domínio da Igreja na formação das mentalidades, mesmo que parte deles fosse dos grupos excluídos, segue-se o discurso dos seus senhores e como não têm voz própria destinam-se a recuperar e propagar os discursos alheios.

A influência religiosa domina a formação do imaginário da população amazônica desde a chegada dos primeiros colonizadores europeus no Pará, seja na capital ou no interior, o pensamento cristão é forte, mesmo quando ligado às manifestações nas quais se percebe a presença do sincretismo. No caso, o "levar uma pisa”, "ser castigado" demonstra que a comunidade cametaense não concorda com a prática homoafetiva, pois foram ensinados a condená-la e recuperam o discurso violento das ordens religiosas usado contra os indígenas durante a invasão ao Novo Mundo. Nesta perspectiva, convém lembrar-se de que:

[...] o escritor latino-americano brinca com os signos de um outro escritor, de uma outra obra. As palavras do outro têm a particularidade de se apresentarem como objetos que fascinam seus olhos, seus dedos, e a escritura do segundo texto é em parte a história de uma experiência sensual com o signo estrangeiro (SANTIAGO, 2000, p. 21).

Por essa razão, entende-se que o julgamento contrário às homoafetividades por considerá-la imoral é produto da formação de mentalidades e da tradição histórica e a intertextualidade, um caminho comum na criação literária.

Fazer uso desse recurso demonstra ainda que os escritores carregam na memória a estrutura dos textos lidos, o que é uma manifestação da memória como lembrança do passado, no qual “encontros memoráveis prestam-se a ser rememorados, menos de acordo com sua singularidade não repetível do que conforme sua semelhança típica, até mesmo conforme seu caráter emblemático” (RICOUER, 2010, p. 42). Compreende-se também que Salomão Larêdo ao usar da intertextualidade com o texto bíblico rememora o seu passado quando provavelmente o leu ou escutou e o caráter emblemático desse faz repercutir nele o desejo de transgredir ao nomear os capítulos do seu romance homo(ama)zônico de estações numa clara alusão à via crucis de Cristo. Por outro lado, ressalta-se que há nesse jogo linguístico a intenção de problematizar a moralidade cristã que prega o amor ao próximo, mas se este não obedecer aos padrões exigidos pela Igreja recebe a condenação e não o afeto. 
Na narrativa, outras personagens homoafetivas também chamam a atenção, porém quase não se fazem notar, uma vez que o fato contrariador da "normalidade" da comunidade Inacha é o casamento homoafetivo entre Inajá e Inajacy, porque à época não se podia pensar em fatos como a aprovação do divórcio tampouco da união entre pessoas do mesmo sexo. Porque para a Igreja e no imaginário social esses fatos violavam a construção do núcleo familiar e ameaçam "o funcionamento da família patriarcal de tal maneira que teve de ser regulado, perseguido e, em alguns casos, eliminado” (OKITA, 2015, p. 42). Outro fator que impulsiona a negação da homoafetividade é a afirmação do sistema capitalista e consolidação da indústria promovida pelo Milagre econômico, que precisava da família para mantê-lo, visto que esta lhes forneceria uma mão de obra barata. Essa noção patriarcalista de família é fragmentada com a presença do filho de Furi e Yur Gagarino.

O filho desmunhecava na frente de toda a comunidade. Bitinho, cabeludo, para muitos, transviado que gosta de twist ${ }^{4}$ e de $l a b a m b a^{5}$, não se continha; era natural sua maneira de ser. Pronunciava inglês perfeito no quarto ano do ginásio e, corpulento, andava compassado, segurando os cadernos à moda das mocinhas. Com a voz macia, sofria sua frescura sem saber como expandir-se naquele lugar pequeno e num colégio de regras rígidas, que o pai recomendava e culpava a mãe, que se lamentava às amigas o filho daqueles modos esquisitos.

E foi exatamente Bitinho - Romualdo Bento - quem arregimentou sua turma, que, armada de facas de ponta e de todo tipo e tamanho, peixeiras afiadas expostas aos montes no jirau feito na frente da casa, terreiro limpo, saiu em defesa do casal, indefeso, evitando a curra fatal (LARÊDO, 2015, p. 21-22).

Evidencia-se, no fragmento, que os estereótipos da homoafetividade masculina identificam Bitinho - o desmunhecar, o corpo ágil para a dança, sobretudo, quando se exigia rebolar, o modo como carregava os cadernos, a voz macia, além de o pai acusar à mãe de culpada pela homoafetividade do filho. Entretanto, durante a repressão militar, a lesbianidade não carregava o mesmo preconceito e violência: “Quem batia um bolão era a Tonta, moleca que se apaixonou por Isabela, a cigana Bella. As duas foram morar e jogar em Altamira, com pseudônimos. Os pais morriam de vergonha delas que se amavam como dois animais. Cada beijo de língua em qualquer parte e lugar, coisa de cinema, dizia a mãe; sem-vergonhice, comentava a outra” (LARÊDO, 2015, p. 164-165). As atitudes de Tonta e Bella sugerem uma reação aos desmandos da cultura patriarcalista e o florescimento do movimento feminista nas décadas de 1960-70, é também uma “crítica brasileira ao machismo e à homofobia” (GREEN, 2000, p. 396).

O romance de Larêdo carrega um discurso de defesa da homoafetividade, indo na contramão aos discursos sociais da comunidade paraense que está mergulhada na existência da tradição e dos costumes, para as quais as

\footnotetext{
${ }^{4}$ Dança surgida nos Estados Unidos, na década de 1960 , os seus dançarinos não carecem de acompanhantes e fazem movimento de rotação com as pernas e quadris.

${ }^{5}$ Música folclórica e pop mexicana, a qual foi lançada, em 1958, pelo cantor Ritchie Vallens e fez tanto sucesso à época que teve sua história contada pelo cinema.
} 
práticas homoafetivas devem ser silenciadas e punidas. A defesa apresentada pelo romancista dialoga com o conceito de memória enquanto parte da identidade de um grupo (CANDAU, 2005) e, por isso, outros podem também se identificar é o que ocorreu com Bitinho, ele só agiu porque foi afetado, sentiu que se ocorria com Inajá e Inajacy, logo, ele também poderia ser vítima da mesma violência.

Do correspondente e enviado especial - Já se aproximando da delegacia, Inajacy, abatida pela dor e vendo suas forças esgotadas, ainda tem ânimo pra consolar grupo de homossexuais que, chorando, lamentavam o sofrimento dela. Dizia:

É esta a parte que me cabe neste latifúndio para que vocês todas possam, um dia, casar sem problemas com os amados de vocês, e que esta sociedade hipócrita...

Novamente o radialista...

A grande multidão suava, o sol intenso. O grupo de homossexuais é considerável.

A noiva, buscando na fraqueza, força, diz:

Bichas de Cametá e de toda parte. Uni-vos! Vai raiar o dia em que seremos compreendidas, poderemos viver sem ter que enfrentar problemas desse tipo. Estaremos livres do preconceito e da discriminação (LARÊDO, 2015, p. 123 - ênfase do original).

A atitude de Inajacy exprime que ela não se torna ruim com a violência do outro, mas em meio à dor, ela ainda tem consciência de que há um preço a pagar quando se assume a identidade homoafetiva, mas nutre a esperança de que, quiçá, tardiamente, homoafetivos tenham o direito de se casar. Também se compreende que Inajacy é conhecedora “dos ideais de tradição patriótica e dos valores patriarcais, das elites brasileiras que sempre se apresentam muito defensivas e, por isso mesmo, particularmente, vulneráveis ao fantasma do desejo desviante” (TREVISAN, 2002, p. 157). Por essa razão, Inajacy sustenta que a sociedade é hipócrita e apela para que os homoafetivos se unam, o que parece sugerir o surgimento dos movimentos de luta pela liberdade sexual e dos homoafetivos vistos a partir de Stonewall.

Percebe-se Inajacy e os que dela se apiedam trazem elementos da memória individual e coletiva acerca das homoafetividades, mesmo que o texto não explicite essa informação, as ações das personagens demonstram que o autor tem consciência acerca das transformações no tratamento dispensado aos homoafetivos. Sobre essas memórias carregadas por quem escreve e ressignificadas no romance de Larêdo, sustenta-se que: "No primeiro plano da memória de um grupo se destacam as lembranças dos eventos e das experiências que dizem respeito à maioria de seus membros e que resultam de sua própria vida ou de suas relações com os grupos mais próximos, os que estiveram mais frequentemente em contato com ele" (HALBWACHS, 2013, p. 51). As memórias (re)lembradas possibilitam uma leitura do que 
foi o passado dos homoafetivos na sociedade brasileira, inclusive no imaginário dos povos amazônicos e, por isso, o narrador dá conta de que a visita do cardeal poderia ajudar a comunidade a mudar a visão dela sobre as homoafetividades.

Esteve naquele espaço, cardeal, enviado especial e espacial, que queria aprender a forma de mudar a indiferença e aceitar a diferença, proceder inclusão, igualdade entre gêneros, o outro como ele é, diverso - no mundo e como resolver as políticas sociais, as práticas de injustiça e corrupção no mundo e a união de pessoas do mesmo sexo. Exortou quem tomava conta das finanças das milhares de ordens religiosas católicas do mundo inteiro e a todos os ricos da face da terra à repartição equânime, com todos, inclusive e sobretudo com os pobres da floresta (LARÊDO, 2015, p. 257, ênfase do original).

O fragmento demonstra que há a perspectiva de mudanças quanto ao modo como os homoafetivos serão tratados pela sociedade e a imagem do cardeal simboliza a desconstrução da educação moralista da sociedade cristã na qual as sociedades foram ensinadas a demonizar as práticas homoafetivas. Nessa desconstrução é defendida a promoção da igualdade de gênero e a união entre pessoas do mesmo sexo, situação que ainda na contemporaneidade sofre a recusa de segmentos das igrejas cristãs, pois estas acusam os defensores da ideologia de gênero e da união homoafetiva de quererem pôr fim à formação da família. Portanto, a crença em novos olhares sobre as homoafetividades também surgiu em meio à repressão imposta pela Ditadura Militar e a punição a Inajá e Inajacy não era por se assumirem homoafetivos, mas por desejarem casar como faziam os casais heterossexuais.

\section{Conclusão}

A história foi pródiga com aqueles que primeiro assumiram a identidade homoafetiva, além de reguladora da sexualidade alheia por conta das convenções da sociedade patriarcal e de instituições que consideram a heterossexualidade normal e a homoafetividade, anormal. A Igreja, na Idade Média, tornou-se a responsável pela difusão desse olhar sobre as identidades e orientações sexuais que fugiam ao padrão heterossexista, pois o discurso bíblico contesta qualquer união que seja diferente da heteronormatividade. No discurso religioso cristão e para os grupos guerrilheiros e políticos homens e mulheres não podem ter orientação sexual diversa da padrão (heterossexual), inclusive aqueles que se encarregam da defesa social ou representam a Nação. Neste sentido, os romances amazônicos lidos dão conta dessas identidades: em Historia de Mayta (1984), a protagonista não serve aos padrões da política trotskista porque é homoafetiva e em Olho de Boto (2015) o casamento homoafetivo é uma afronta à moralidade da comunidade de Inacha, Cametá, Belém, Brasil. 
Historia de Mayta (1984), de Mário Vargas Llosa, não é, particularmente, um romance homoafetivo, visto que a orientação sexual da personagem-título não é a principal discussão da obra, mas a sua fé sectária e participação no POR, mais tarde, quando dissidente no POR(T), partidos políticos representativos da classe operária nos quais ele militou. Do último, a personagem ainda foi o responsável pelo jornal Voz Obrera, o qual servia para propagar os seus ideais de revolução, contudo, após os companheiros saberem que Mayta é homoafetivo, ele foi expulso do partido e ainda foi para a prisão, por diversas vezes e, na última, acusado de sequestro e, por isso, pegou pena de quinze anos de reclusão. Percebe-se que Mayta não é punido pelas autoridades policiais, as quais comandavam os tempos de repressão por representarem o braço armado do Estado, por sua identidade pessoal, mas para reprimir os comportamentos considerados subversivos à ordem social. Então, Mayta não é preso por ser homoafetivo, mas por ser ativista político da esquerda representativa do operariado. Quanto à expulsão do partido não é culpa do poder, e sim do próprio grupo que ele representara.

Olho de Boto (2015), de Salomão Larêdo, por sua época de produção e circulação pode ser considerado como estritamente pertencente ao sistema literário homoafetivo, uma vez que o tema central é o julgamento acerca do casamento do casal Inajá e Inajacy. Por outro lado, o autor é subversivo por tratar dessa temática e situá-la na comunidade fictícia de Inacha, em Cametá, além de fazer uma intertextualidade do texto bíblico dos evangelhos os quais tratam do julgamento e da condenação de Jesus Cristo. Inclusive ao nomear os capítulos dá a eles o nome de estação, mesmo nome dado às etapas - do julgamento e condenação ao enterro de Jesus, e nos três últimos inova ao quebrar o horizonte de expectativas do leitor que já previa a condenação do casal. Depois de preso, é solto, Inajá e Inajacy dançam a valsa e se casam. O julgamento dos noivos não é a confissão de que a sociedade cametaense foi ensinada desde a colonização a repudiar o amor homoafetivo, isso só acontece porque eles vão além dos limites do privado - querem casar-se, como todo casal que se ama. Assim, a punição acontece, são julgados e presos, mas a liberdade anunciada no período da repressão é obtida mais tarde, eles se casam e ainda dançam a valsa como representação plena da felicidade.

Dados históricos e as lembranças dos tempos da repressão se fundem e ecoam nos ouvidos dos leitores de Mário Vargas Llosa e Salomão Larêdo, como se passasse um filme diante de suas retinas e eles fossem transportados no tempo para Malecón de Barranco, Jauja ou Inacha. Os dramas vividos pelas personagens aproximam-se das histórias que por diversas vezes já se leu ou ouviu de como era a vida nos tempos da repressão militar, contudo, para os homoafetivos, esse tempo mesmo injusto, impiedoso, é também o prenúncio da esperança de que um dia as pessoas que assumem a identidade homoafetiva poderiam ser respeitadas. Em ambos os romances, a contestação aos homoafetivos não ocorre porque eles assumem a sua identidade sexual, mas porque são tomados como subversivos e é esse comportamento visto 
como amoral que é punido. Portanto, as vidas homoafetivas nos tempos da repressão têm sua subjetividade encarcerada, silenciada porque imputam a elas novas práticas. São sequestradores, ladrões, prostitutas que desafiam a moralidade e esse tempo é também quando se vislumbra a partir dos movimentos surgidos um novo olhar para os sujeitos com essa identidade.

\section{Referências}

CANDAU, Jöel. Antropologia da memória. Trad. Miriam Lopes. Lisboa: Instituto Piaget, 2005. (Coleção Epistemologia e sociedade).

CANDIDO, Antonio. Literatura e sociedade. 8. ed. São Paulo: T. A. Queiroz. Publifolha, 2000. (Grandes nomes do pensamento brasileiro).

CANDIDO, Antonio; ROSENFELD, Anatol; PRADO, Décio de Almeida; GOMES, Paulo Emílio Salles. A personagem de ficção. 13. ed. São Paulo: Perspectiva, 2014. (Coleção Debates).

COWAN, Benjamin. Homossexualidade, ideologia e "subversão" no regime militar. In: GREEN, James N; QUINALHA, Renan. (orgs.). Ditadura e homossexualidades: repressão, resistência e a busca da verdade. São Carlos: EdUFSCar, 2014.

DERRIDA, Jacques. Essa estranha instituição chamada literatura: uma entrevista com Jacques Derrida. Trad. Marileide Dias Esqueda. Belo Horizonte: UFMG, 2014.

FIGARI, Carlos.@s outr@s cariocas: interpelações, experiências e identidades homoeróticas no Rio de Janeiro: séculos XVII ao XX. Belo Horizonte: UFMG; Rio de Janeiro: IUPERJ, 2007.

GREEN, James Naylor. Além do carnaval: a homossexualidade masculina no Brasil do século XX. Trad. Cristina Fino e Cássio Arantes Leite. São Paulo: UNESP, 2000.

HALBWACHS, Maurice. A memória coletiva. Trad. Beatriz Sidou. 2. ed. São Paulo: Centauro, 2013.

JOZEF, Bella. Prefácio. In. LLOSA, Mário Vargas. História de Mayta. O romance mais polêmico dos últimos tempos. Trad. Remy Gorga Filho. Rio de Janeiro: Livraria Francisco Alves, 1984.

LARÊDO, Salomão. Olho de boto. São Paulo: Empíreo, 2015.

LE GOFF, Jacques. História e memória. Trad. Bernardo Leitão. 7. ed. rev. Campinas: Editora da Unicamp, 2013.

MERGIER, Anne-Marie. Vargas Llosa: Génesis de la Historia de Mayta. Huellas, n. 14 Uninorte. Barranquilla, p. 10-14, Abril, 1985. Disponível em: <http://ciruelo.uninorte.edu.co/ pdf/huellas/14/Huellas_14_2_ VargasLlosaGenesisdelahistoriadeMayta.pdf>. Acesso em: 30 jun. 2017. 
MOTT, Luiz. Etno-história da homossexualidade na América latina. Seminário Taller de História de las Mentalidades y los Imaginarios, Pontíficia Universidad Javerina de Bogotá, Colômbia, Departamento de História e Geografia, 1994. (Comunicação oral). Disponível em: <http:// wp.ufpel.edu.br/ndh/files/2017/02/04.-Luiz_Mott.pdf>. Acesso em: 01 jul. 2017.

OKITA, Hiro. Homossexualidade: da opressão à libertação. 2. ed. São Paulo: Sundermann, 2015.

RICOUER, Paul. A memória, a história, o esquecimento. Trad. Alain François et al. Campinas: Unicamp, 2010.

ROSSI, Paolo. O passado, a memória, o esquecimento: seis ensaios da história das ideias. Trad. Nilson Moulin. São Paulo: UNESP, 2010.

SANTIAGO, Silviano. Uma literatura nos trópicos: ensaios sobre dependência cultural. 2. ed. Rio de Janeiro: Rocco, 2000.

TREVISAN, João Silvério. Devassos no paraíso: a homossexualidade no Brasil, da colônia à atualidade. 5. ed. rev. ampl. Rio de Janeiro: Record, 2002.

VARGAS LLOSA, Mário. História de Mayta. O romance mais polêmico dos últimos tempos. Trad. Remy Gorga Filho. Rio de Janeiro: Livraria Francisco Alves, 1984.

YATES, Frances Amelia. A arte da memória. Trad. Flavia Bancher. Campinas: Unicamp, 2016.

Recebido em outubro /2017.

Aceito em novembro/2017. 